\title{
Finnegans Wake: Beyond the Limits of Translation ${ }^{1}$
}

\author{
Finnegans Wake: más allá de los límites de la traducción
}

ESMERALDA OSEJO BRITO

Investigadora independiente | México

Contacto: esmeralda.osejo@hotmail.com

\begin{abstract}
Many deem James Joyce's Finnegans Wake an untranslatable novel. Despite this, the characteristics that appear to obscure its meaning, such as semantic multiplicity and experimental syntax, also make it particularly open to interpretation and resignificationthus, to translation. The present paper proposes a flexible, creative, playful, and free approach to its translation. I discuss the possibilities derived from such an approach through the analysis and translation of fragments of Finnegans Wake into Spanish, and I support this approach to the translation process with some of the most prominent research on the translations of Joyce's works, up to date scholarship from Translation Studies, and relevant testimonies from Joyce himself and from translators and writers who have studied his literary production. I argue that Finnegans Wake is a text that tries to capture language itself, transcends linguistic barriers by resisting rigidity of meaning, and achieves an "openness" and freedom that, paradoxically, have somewhat limited the efforts to translate it. Therefore, I propose that if Joyce did not limit himself in his creative process, it is necessary that we, as readers and translators, accept without fear the challenges presented to us by Finnegans Wake and dare to create new art from it.
\end{abstract}

Keywords: Finnegans Wake, translation, Spanish, Joyce, Ireland

\section{Resumen}

Muchos consideran la obra Finnegans Wake de James Joyce una novela intraducible. Sin embargo, las características que parecen oscurecer su significado, como la multiplicidad semántica y la sintaxis experimental, también la hacen particularmente abierta a la interpretación y a la resignificación; por tanto, a la traducción. El presente artículo propone un enfoque flexible, creativo, lúdico y libre para su traducción. En él discuto las posibilidades derivadas de tal enfoque a través del análisis y traducción de fragmentos de Finnegans Wake al español, y apoyo esta aproximación al proceso de traducción con algunas de las investigaciones más destacadas sobre la traducción de la obra de Joyce, investigación académica en la disciplina de estudios de traducción, y testimonios relevantes del propio Joyce y de traductores y escritores que han estudiado su producción literaria. Asimismo, sostengo que Finnegans Wake es un texto que intenta capturar el lenguaje en sí, trasciende las barreras lingüísticas resistiendo la rigidez del significado y logra una "apertura” y libertad que, paradójicamente, han limitado en cierta medida los intentos de traducirlo. Por eso propongo que, si Joyce no se limitó en su proceso creativo, es necesario que nosotros, como lectores y traductores, aceptemos sin miedo los desafíos que Finnegans Wake nos presenta y nos atrevamos a crear nuevo arte a partir de él.

Palabras clave: Finnegans Wake, traduccion, español, Joyce, Irlanda

${ }^{1}$ This paper is based on a talk I gave in Spanish in 2019, titled "Finnegans Wake: Más allá de los límites de la traducción.” 


\section{Introduction}

$\mathrm{T}$

he etymology of the Spanish word apertura (an opening, the quality of being open, or the action of opening) goes back to the Latin word aperire and refers to that which is exposed, revealed-that which is not closed or hidden. In this paper, I want to propose that the most suitable way to approach the translation of Finnegans Wake is not a rigorous, academic one, but rather a remarkably flexible and free one, where enjoying the manipulation of language is just as important as translating meaning. I support this proposal by analyzing some of the most prominent investigations on specific translations of Joyce's works, up to date scholarship from Translation Studies, and relevant testimonies from Joyce himself and from translators and writers who have studied his literary production, as well as my own experience translating fragments of it into Spanish. I argue that the features that appear to constitute insurmountable barriers for the translation process of Finnegans Wake are the same that make it a highly translatable work.

The main function of language is to communicate, and its main characteristic is that it signifies - it conveys meaning. Starting from this, one may think of Finnegans Wake as an isolated code, like a surviving manuscript of a dead language, which is unable to effectively fulfill the purpose of communicating. It tries to communicate but, as there is no common code between sender and receiver (to use Roman Jackobson's terms), reading it is like coming in contact with a new language. The "normal" English words intertwined in it with Joyce's made-up words are not enough to render a truly familiar text to the reader.

The first impression while reading the novel is that the self-isolation of a work written in a code that no other work or human (other than its author) shares constitutes an insurmountable barrier for both readers and translators. Moreover, because of the ambiguity contained in its polysemic words and its fluctuating structure, it is difficult to know what its topics or characters are, and whether there is a meaning and purpose behind these alterations to the English language. We cannot know for certain if the narrative style recreates the language of dreams or the speech of a drunkard. Reading it multiple times seems unavoidable, not only 
in a quest for meaning but also for entertainment. However, this does not imply that its meaning is concealed or hidden: it lies scattered in the pages, open right in front of us, in thousands of possibilities within reach of anyone who is willing to make the effort (or, perhaps, has the openness) to find them. Patrick O'Neill (2014) already said it in Impossible foyce: "Finnegans Wake is a literary machine designed to generate as many meanings as possible for as many readers as possible" (3). If "each language in particular constitutes a specific segmentation of reality" (Bordenave, 2012: 45), in this case we find a code which represents Joyce's unique perception of reality. Not only that but, as O'Neill states, it keeps growing and changing through its readings and translations.

It seems contradictory to assert that a work of this sort, which countless times has been called untranslatable and which is usually considered to have an obscure meaning (Vázquez, 2017), is not only possible, but fun to translate. Some critics and writers have even stated that it is total nonsense. However, this has not prevented other writers and translators from interpreting and translating it. O'Neill has devoted a whole book to the historical record of dozens of attempts at translating it, some of them in its entirety, in over ten different languages, and another book to his theory of the Joycean "single polyglot macrotext," which implies a transtextual reading of all the translations of each of Joyce's works as if, together with their source text, they were one ever-expanding (macro)text (O’Neill, 2005; 2014). Likewise, Umberto Eco (1996: XI), with his incredible creative genius, claimed that it is indeed the easiest of all texts to translate, despite being a text that "takes language beyond any boundary of communicability" (61). Not only this, but there is an avid audience waiting for its translations. The 2013 Chinese translation by Dai Congrong, for example, "was an instant bestseller, clearing through its initial print-run of 8,ooo copies in one month. It is now in its second print-run of 5,ooo copies and is still being discussed" (McGrath, 2014: n. p.).

It is interesting to think that, perhaps, Joyce simply wanted to entertain the readers as he had entertained himself during the creation process; he even wrote about how he had laughed at his own jokes and puns as he wrote it (and who among us does not enjoy a private joke?) (O’Brien, 2017). It is also said that he wrote 
Ulysses as a joke for the sole entertainment of his friends. Then, just as Joyce had fun playing with words in multiple languages, we should not refrain from doing the same.

In Spanish, the most recent translations of Finnegans Wake are those by Marcelo Zabaloy, who chose to keep the English title, published for the first time in 2016, and by Juan Díaz Victoria, who chose to title it Estela de Finnegan (in Spanish, estela refers to the wake of a ship or to a trace something or someone leaves behind). Díaz Victoria has only published the first chapter and is looking forward to completing the rest in the following years. Apart from these two, other translations into Spanish are only fragments, as the well-known and overly annotated translation of the first page by Salvador Elizondo, and the "simplified" version by Francisco García Tortosa. So far, there is an evident need for more translations to be done in this language.

\section{Mechanisms of the Wake}

Edna O'Brien (2017), the Irish novelist and playwright, says that, in his fifties, "IJoyce] admitted that he was at the end of English, saying he could no longer use ordinary words with daytime association, as [Finnegans Wake] was a book of the night, "bauchspeech from his innkempt house'” (n. p.). With Finnegans Wake, polysemy is not confined to the written code because it uses phonetics (sound) as a determining element of meaning. Sound becomes a key element of the riddle. To discover double or multiple connotations it is usually necessary to read (or at least think) the words out loud; furthermore, the sounds of Finnegans Wake evoke words in other languages, onomatopoeias, rhythms, and dialects, among others. There are myriads of examples, such as "I rose up one maypole morning" (Joyce, 1958: 249.26), "He is shinkly thinkly shaking in his schayns" (Joyce, 1958: 342.29), "(pip, pip, pip) willpip futurepip feature apip footloose pastcast with spareshins and flash substittles of noirse-made-earsy" (Joyce, 1958: 314.25-26). Sounds appear to be one of the foundational pillars of the work. 
If Joyce was "at the end of English," with all that such a statement implies, I think it is necessary for us to detach ourselves from the traditional concept of signified-signifier and approach Finnegans Wake more as a living generator of meanings than as a fixed English text. Beyond communicating the multiple sources that engendered it, Finnegans Wake communicates itself as a multifaceted whole, as a work of alchemical transmutation. Regarding this, James. S. Atherton (1959) stated in The Books at the Wake: A Study of Literary Allusions in Fames foyce's Finnegans Wake that "Joyce believed that his words were 'Words of silent power' [...] he believed that he was entrapping some part of the essence of life within [Finnegans Wake's] pages [...] that somehow the spirit of language was working through him of his own volition [...] Joyce was not in his own opinion simply writing a book, he was also performing a work of magic" (15). As mentioned by Atherton, Joyce drew from Arthur Symons' (1899) The Symbolist Movement the ideal "to evoke, by some elaborate, instantaneous magic of language, without the formality of an after all impossible description; to be rather than to express" (130). Indeed, Finnegans Wake is an attempt at capturing the very essence of language itself. If it is a work that is synonym with innovation, then it must be translated in innovative ways.

Yet, there are several languages in which not many attempts have been made at translating the text in its entirety. This was the case with Spanish, until Marcelo Zabaloy's translation appeared. He refused to believe that it was impossible to translate, and just did it. Polemic as his translation may be because it comes from someone who does nothave an (official) academic background, overall, the reception of this translation has been excellent. It has opened the world of Finnegans Wake to Spanish speakers who do not read in English and who would have never had access to it otherwise, and to whom the reading of it has brought great pleasure (Savino, 2016). After all, Zabaloy is a polyglot himself, as well as an avid reader. This shows how necessary it is to attempt to translate Finnegans Wake from the mindset of flexibility and enjoyment, and to dare to exploit the creative mind in doing so. Even if we were to try to attach a fixed meaning to each of the novel's words, how could we determine and analyze the subjective and individual experience, the evocations 
produced by sound? Or even more, how would we delimit the impression produced by that whose meaning is intuited but never clearly delineated?

I personally find myself fascinated by what Zabaloy has achieved; there is a musicality, a certain quality to the words he created that makes his translation so pleasurable to read. It is as if I were able to taste them, to savor them while I read them. It opens new possibilities of beauty and playfulness for the Spanish language, already beautiful. Even for me who, despite being a native Spanish speaker usually prefer to read the source texts in English, this is an exception. Likewise, I am sure there is a pleasure that only a native English speaker can derive from reading Joyce's Finnegans Wake.

Díaz Victoria, like Zabaloy, intends to translate the entirety of Finnegans Wake but, so far, his approach seems slightly reductive, a tendency we can appreciate from the very beginning with his choice of words for the title: Estela de Finnegan. The word "estela" seems quite limited because it does not really allow for more than one reading: the trail that follows the course of something, particularly a boat in the water. This reading can be pushed and perhaps interpreted in some other ways, such as the translation following the source text like a wake, but I feel it would be asking too much of it and definitely not the first reading. The interpretation of "wake" as waking up, awakening, and as a funerary ceremony (all arguably more prominent in English) is lost. Likewise, his choice of getting rid of the "s" in the word Finnegan deprives it from the openness and ambiguity that the letter and the lack of apostrophe give it in English. It is harder to feel the playfulness, the fullness of Joyce's Finnegans Wake in this translation. Díaz Victoria's (2016) "correrrío, pasado lo de Eva y Adán, desde viraje de ribera hasta recodo de bahía” (29) lacks the rhythm and musicality of Zabaloy's "riverrante, pasando Eva y Adán, de curva ribereña a codo de bahía" (Joyce, 2016: 1) and would appear to privilege meaning over style or form. Moreover, the illuminating but excessive footnotes make the reading stumble.

So, if we stop trying to capture all the "hidden" meanings, we can change our point of view. We can take a step back, look at all the elements that have been deemed untranslatable with an open mind, and realize that, as a matter of fact, all 
these elements can be the translator's best allies. Finnegans Wake provides us with an immense number of tools for translating it: words in dozens of other languages, onomatopoeias, sounds, metaphors, music. This means that we, as translators, can resort to these same elements in our target language. Colm Tóibín (2016) states that, when Joyce was writing A Portrait of the Artist as a Young Man, "he set out, as he wrote, 'to forge in the smithy of my soul the uncreated conscience of my race' by finding a tone and a form to suggest that the dull, provincial city we lived in could be made the centre of the known universe" (n. p.). Finnegans Wake is the epitome of this mission.

Critics could perhaps accuse Zabaloy of taking many liberties or of using localization in some passages (and is not Finnegans Wake full of dialects and sociolects?), yet this is precisely the style of translation that Joyce himself encouraged, and in order to emulate the style and effect of the source text on its audience, this is the ideal stance to take. Moreover, one could ask, where do we draw the line between the necessary changes that any translation entails and "taking liberties"? The line between expert and snob? Could we not say the same about those who have used it as visual material for their paintings; that they have appropriated it and detached it from its original structure, format, and purpose? Is it not that sort of attitude that Joyce hated so much? For an author who claimed there was not a single serious word in Finnegans Wake, who refused to call himself modernist or to be encased in a genre, who refused to be tied to a country that he both hated and loved, it is obvious that freedom and fun were very important to him, and so it would make sense that translations of his freest work should abide by the principles of freedom, flexibility, and playfulness.

\section{The translation process}

The phrase "binomeans to be comprendered," among others, exemplifies the multiplicity of interpretative possibilities in Finnegans Wake. I have chosen it because, for me, it is a sentence that represents the totality of the work. At first sight, it could be read as "by no means to be understood," or as "binomials to 
be comprehended," to give two examples. I also read it as "by no means to be completely rendered." In Figure 1, I have traced a map of possible translations for each element of the phrase into Spanish. It is possible to trace different nets of meaning connecting each of these elements in many different combinations. The left column shows potential translations for the first element, "binomeans," the one in the middle shows potential translations for the second element, "to be," and the right column shows potential translations for the third element, "comprendered." The colors of the lines are meant to indicate possible routes or combinations for translation, depending on the set of meanings that the translator wants to privilege. For example, it would be completely valid to say "con binoforma de ser desentrendido," following the blue lines, or "imposible de ser compretamensible," following the red lines.

\section{Figure 1}

Map of possible translations of the phrase "Binomeans to be comprendered" into Spanish

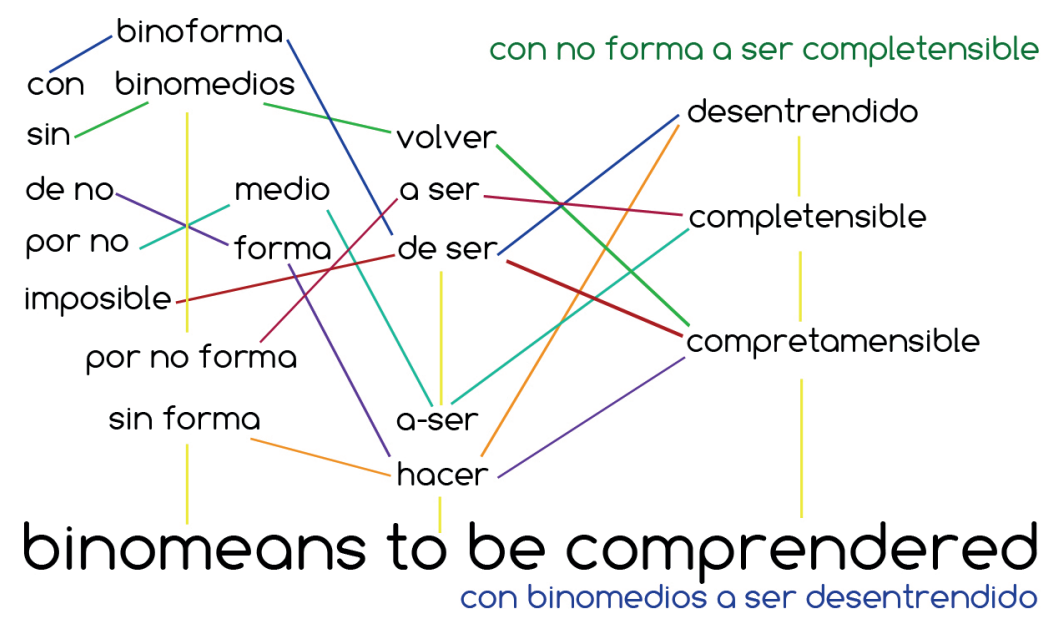

Source: Copyright 2019 by Author

The first one privileges the duality of "binomial" or "binomen" and "no means," and on top of it adds a third meaning through the word "forma," or "shape," creating 
"with no shape" as yet another reading. It then chooses "de ser" as the literal translation of "to be," and privileges the meaning of "untangled" or "unraveled" and "understood" with the combination of the Spanish words "desentrañado" and "entendido." The second one discards the duality in the first element and chooses to privilege the strength of the meaning "by no means," which would potentially be the strongest phonetical reading, followed again by the literal "de ser" translation of "to be," and finally privileging the meaning "completely" and "comprehensible" by combining the words "comprensible" and "completamente." It must be noted, in this translation, that the sound of the made-up word "compretamensible" is very close to the sound of the word "comprendered."

In the end, the two translations I personally like the most are "con no forma a ser completensible" and "con binomedios a ser desentrendido," which I have showed in green (top right) and blue (bottom right), respectively. However, of these two I would choose the second, "con binomedios a ser desentrendido," because not only does it preserve the semantic multiplicity of Joyce's phrase, but it is also the closest both visually and phonetically to its source. This is the reason why I have placed it right below the original. The first element of the translation privileges the meaning "ways" or "methods" through the Spanish "medios," as well as "binomials" in the word "binomios," which combined form "binomedios." This is, in my opinion, the translation that most closely resembles the original duplicity. Then, "to be" is translated as "a ser," which is a future-time form of the verb "to be," but can also be understood as "to do" when read out loud, being a homophone of the word "hacer" (literally, "to do"). And then again, "desentrañar" means "to untangle" or "to unravel," and "entendido" means understood. This means that the whole phrase in Spanish can be understood to mean "impossible to comprehend," "through binomials to make incomprehensible," and "through binomials to be unraveled" at the same time.

I particularly like this result because it reminds me of the different ways a translator can approach Finnegans Wake: considering it impossible to understand and impossible to render in a different language, or considering that, through the artful use of polysemic words, it is possible to untangle and translate. According to 
Anton Popovič's definition of translation equivalence, the approach both Zabaloy and I have taken at translating Finnegans Wake could potentially be classified as "Stylistic (translational) equivalence, where there is 'functional equivalence of elements in both original and translation aiming at an expressive identity with an invariant of identical meaning"' (Bassnett, 2002: 33). Both approaches fall into Eugene Nida's category of dynamic translation, as "based on the principle of equivalent effect, i.e. that the relationship between receiver and message should aim at being the same as that between the original receivers and the SL message" (Bassnett, 2002: 34). However, I believe that translating Finnegans Wake takes something more than determining and sticking to one among many translation methods that have been categorized one way or another in the academic world. It requires a specific attitude towards it and a peculiar ability to enjoy it.

The multiplicity of meanings that I have presented in relation to one single phrase, "binomeans to be comprendered," expands in an infinite number of possibilities if we consider all the variables and possible renderings of each word, phrase, sentence, onomatopoeia, or metaphor that makes up the totality of Finnegans Wake. If we add to this the connotative changes of words over time and in relation to geographical location, as well as the perceptual differences at the individual level, we will find that this infinite capacity for reconfiguration is the very essence of Finnegans Wake. This work is a linguistic kaleidoscope that not only allows, but also invites innumerable translations. And, since it is already widely accepted that every translation is a new work in its own right, the task of translating Finnegans Wake is the task of creating a new, beautiful polysemic work.

\section{Discussion}

What is, then, our duty as translators, as readers, as writers, regarding this pluribelle, multi-faceted work, both repudiated and revered? It is natural, of course, to feel tempted to try to cover all the possible meanings contained in it, or, at least, to write them down in footnotes, as Salvador Elizondo did in his time. If the translator attempts to do this, their research might become an unsurmountable 
obstacle that threatens to be endless. Because of the characteristics Ihave discussed, Finnegans Wake will keep unraveling and we will keep adding layers of meaning to it, even layers that were not intended by its author but that we have created through our individual cultural background, experience, and biased reading of it (as happened with my translation that included the word forma, or "shape"). Making a final decision will then be almost impossible. To avoid this, I would recommend to be very clear about what our Finnegans Wake is; what it means for ourselves and ourselves only, because this is the only meaning of which we will ever be certain.

There is no denying that Joyce must have been thinking of a specific meaning or set of meanings for each word he composed; in a letter to Harriet Shaw Weaver, he stated that "Wolken" meant "a woollen cap of clouds" and "passencore" corresponded to "pas encore" and "ricorsi storici" of Vico (O’Brien, 2017: n. p.). However, Frank's testimony (as cited in Chrisp, 2017) tells us that Joyce did not hesitate to completely change the meaning when translating Finnegans Wake into Italian:

The rhythm, the harmony, the density and the consonance of his words were more important to them than their meaning, and that, for example, having written one thing, Joyce scarcely hesitated to put down something completely different in Italian, as long as the poetic or metrical result was equivalent [...] [he] felt the same delight in playing games in Italian as he did with English. (n. p)

According to the testimony of Nino Frank, the film critic who helped Joyce do his Italian translation of the "Anna Livia Plurabelle" chapter, Joyce himself had told him: "We must begin work before it's too late. For the moment there is still one person in the world, myself, who can understand what I have written. I can't guarantee that in two or three years I will still be able to" (as cited in Ellman, 1983: 700). Umberto Eco (as cited in Chrisp, 2017) also noted that Joyce "was seldom bothered if the Italian text said different things from the English text" (n. p.) and stated that the Italian version makes it easier to understand the inner mechanisms 
of Finnegans Wake, and that "the truth is that Joyce did not care a whit for any of our translation problems. What he wanted to do was invent an expression like 'Ostrigotta, ora capesco"” (Chrisp, 2017: n. p.). This is yet another argument in favor of the freedom and openness allowed to a translator who intends to work on Finnegans Wake.

After considering these statements, it is interesting to note that the prolific translations into French and Italian, both Romance languages like Spanish, did not show the revering and hesitant attitude of certain translators and critics in Spanish. This could have been because Joyce himself initiated those translation efforts and influenced the translators with his approach. This makes me wonder if what is needed to bridge the gap that prevents the realization of more long translations into Spanish and other languages is less theory and more of the fun, fearless, and even slightly irreverent attitude of someone like Zabaloy, a life-long computer technician who does not hesitate to ask "What is the problem with some dude from La Pampa who has just come out from beneath a slab doing this? Who can be upset about it?"” (Calero, 2016: n. p.; my translation). . Certainly, not James Joyce.

The flexible translation approach I propose for this work lies in between a source-oriented and a target-text-oriented translation process, although one could argue that it is perhaps closer to the target-oriented "skopos" theory, which proposes that the main determinant of the translation strategy is the translation's purpose. Nevertheless, it is always good to remember what Lynne Long (2007) has clearly stated: "that translation principles cannot always be defined and adhered to like scientific formulae, but at times remain as flexible and as fickle as language itself" (63).

Failing to know each and every one of the multiple connotations and meanings of each word does not exempt us from translating, nor does it exempt us from our responsibility to understand what we can understand. It is necessary that we ourselves make a new painting, a translation that creates a feeling of

${ }^{2}$ In the original: “¿Cuál es el problema de que un tipo de la Pampa que sale debajo de una baldosa haga esto? ¿A quién le puede molestar?" 
encountering a new language and that allows the readers to unfold its meanings as they reread it. Therefore, both its exquisite reservoir of resources and its form-a recirculating mechanism that tries to follow the living nature of languages-as well as Joyce's own writing methods, offer a great opportunity for a most entertaining translation feat.

An example of a peculiar interpretation of Finnegans Wake is that by Robert H. Boyle (2000), founder of the Riverkeeper and the Hudson River Foundation and author of The Hudson River: A Natural and Unnatural History. He proposed that the main theme of the work was fishing and fish. Boyle even went as far as to make an account of the number of fish species and words related to fish which he had found in it. Others, like Harold Bloom, claim that Shakespeare is its cornerstone, and some others that it is a story about a river, or about women.

Furthermore, not only can we translate Finnegans Wake interlinguistically; it is a work that lends itself to intersemiotic translation (across different media and platforms). Among the artists who are already creating art inspired by Finnegans Wake are Peter O'Brien, with his collection "Lots of Fun with Finnegans Wake," and Carol Wade, with her work in progress "Art of the Wake," which she presented in June 2019 at the Joyce Without Borders International Symposium. These works take fragments of Joyce's work, detach them from their original context, and turn them into visual elements within their paintings, thus turning the written word into an inseparable element of a visual composition. I also resorted to creating a visual composition (the map presented in Figure 1) for my translation of the sentence "binomeans to be comprendered," playing with colors, lines, and arrangements in space. Translating Finnegans Wake is an act of revolt against one's limits; therefore, it is perfectly aligned with the poetics of its author. If Joyce did not accept any limits or boundaries, it is compulsory that we ourselves, as readers and translators, face without fear the challenges presented by his final work.

We might then wonder what other products can be created from Finnegans Wake; if it would be possible, for example, to create an interactive book for kids where they could touch the different words and hear different translations, the same way an interactive plush makes different sounds every time someone squeezes it. 
Or to decorate a house with its extravagant onomatopoeias inscribed on ceramic tiles. Or a virtual game where the reader could play with different translations to their hearts' content. The possibilities seem endless.

\section{Conclusion}

As we have seen, Joyce wrote a work that deliberately deludes critics and theorists. However, he wanted it to be recognized and enjoyed; otherwise, he would not have made such an effort in writing apologies for it, like the (sort of) nursery rhyme he wrote to promote the edition of the "Anna Livia Plurabelle" chapter. He wanted to have fun, create puns, enjoy playing with words, and entertain his readers. He was the first to attest to its translatability and to commission and supervise translations of it in Italian and French, both of which he spoke.

A fearful approach to translating Finnegans Wake does not honor Joyce's spirit. Moreover, the multiplicity of elements such as its polysemic words, metaphors, rhythms, sounds, and experimental syntax allow for an open, flexible translation that can be approached in a playful way, trying to emulate the process of creation of Joyce's Finnegans Wake and his explicit attitude towards translating it. These characteristics that appear to obscure its meaning are the same that make it particularly open to interpretation and resignification; that is, to translation. They encourage us to share it, recreate it and use it as an infinite food for the imagination. In this sense, Finnegans Wake is "like an open book" (como un libro abierto). It is a painting of magnificent words, of colors created in a palette of varied languages, a painting that represents the sound of the river, the beauty of the ordinary and of the ugly, the melody of slang and drunkenness, the hope for resurrection, a painting that cannot be caged in a fixed frame of meanings. It will keep growing as a macrotext, as O'Neill calls it, as it keeps being reframed, translated, reinterpreted.

Figure 2 shows two shots of one single hummingbird, taken almost at the same time. At first glance, the birds seem to belong to two different species; however, the only difference between one picture and the other is the direction of the light 
that hits the bird's iridescent feathers. The same happens with Finnegans Wake; it is one single work that, like a hummingbird, drastically changes depending on the light under which one reads or translates it. If this could be said about many literary works, it is even more so the case for the extremely polysemic Finnegans Wake.

\section{Figure 2}

Sequential shots of an Eugenes fulgens hummingbird, also known as Rivoli's Hummingbird

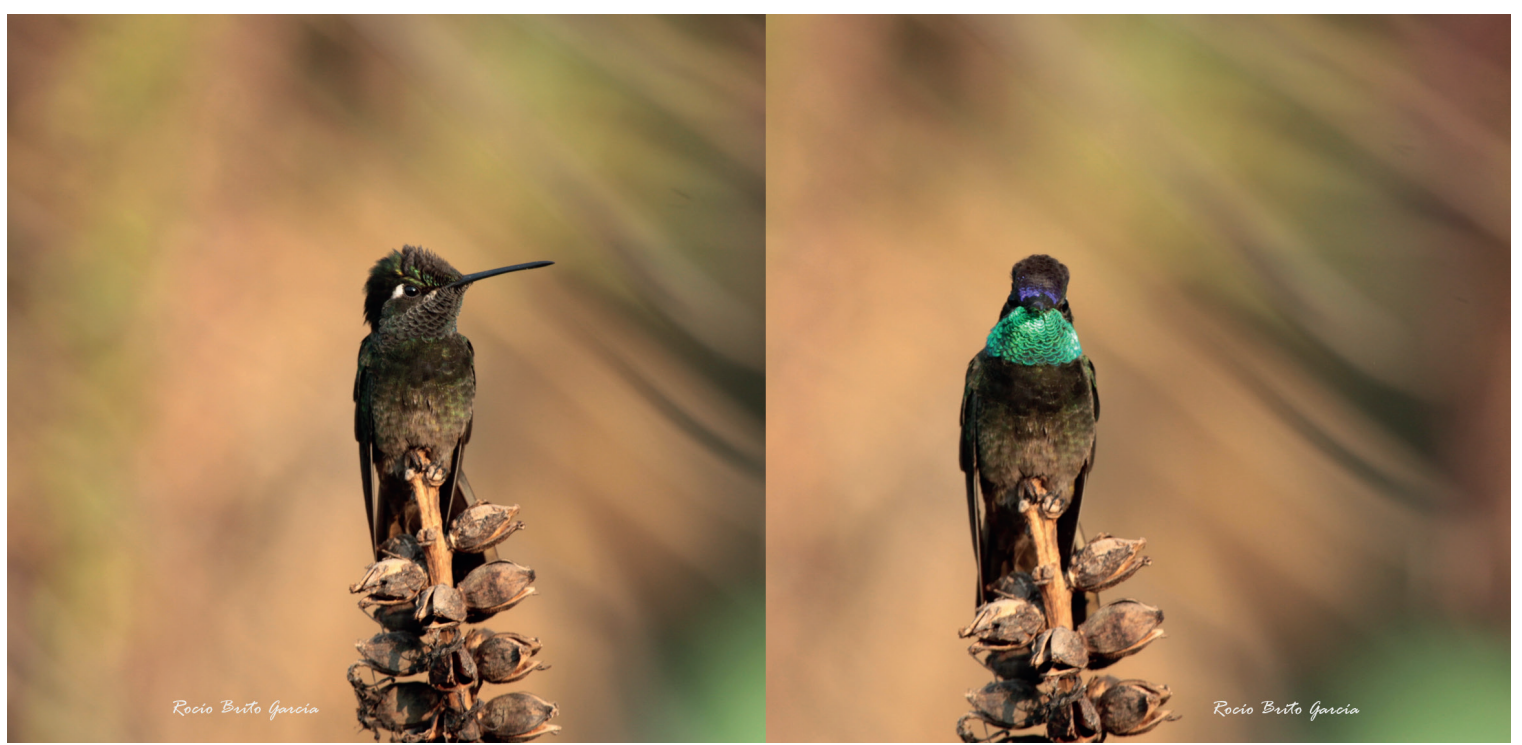

Note: This bird's appearance changes drastically depending on the angle in which light hits its iridescent feathers. Source: Copyright 2019 by Author. Photographs: Copyright 2019 by Rocío Brito García. Used with permission.

I believe that, in order to translate it, we must turn our eyes towards the artist in ourselves. This does not mean that reading all the theoretical and critical comments made by experts on it and carrying out thorough research is inappropriate. Even Zabaloy kept the website Finnegans Wake Extensible Elucidation Treasury ${ }^{3}$ and the

${ }^{3} \underline{\mathrm{http}: / / \text { fweet.org/ }}$ 
French translations at hand at all times. What it means is that the translator should let go off any academic rigidity and privilege creativity, a sense of fun, and love for language above any attachment to the concepts of fidelity, literality, or respect, already highly contended in the field of Translation Studies (Munday, 2008), or to any specific method of translation. It even means not being afraid to transcreate or do an intersemiotic translation of it, into any medium or platform. Moreover, there is no reason why this could not be done as a collective translation by a group of confident people who fancied playing with their chosen target language.

This is a task intended for the most devoted language lovers; for the greatest admirers of the work of Joyce, the master of language. We must become artists, and each draw a new Finnegans Wake, one that recirculates infinitely in a comodio vico.

\section{WORKS CITED}

AtherTon, James S. (1959). The Books at the Wake. Faber and Faber.

BASSNETT, Susan. (2002). Translation Studies (3rd Edition). Routledge.

BordenAVE, Maria Candida. (2012). "The Cultural and Ideological Barriers in the Translation Activity." Tradução em Revista, (13), 43-50. https://doi.org/10.17771/ PUCRio.TradRev.20911

BOYLE, Robert Hamilton. (2000, July 23). "You Spigotty Anglease?" The New York Times. Retrieved on 15 February 2021 from http://movies2.nytimes.com/ books/00/07/23/bookend/bookend.html

CALERO, César G. (2016, July 27). “¿Alguien dijo que el 'Finnegans Wake’ era intraducible?" El Mundo. Retrieved on o6 May 2021 from https://www.elmundo.es/ cultura/2016/07/22/5790a6db46163fe33e8b4658.html

CHRisP, Peter. (2017, January 31). "The Italian Anna Livia Plurabelle" [Blog entry]. From Swerve of Shore to Bend of Bay. Retrieved on 15 February 2021 from http:// peterchrisp.blogspot.com/2017/o1/the-italian-anna-livia-plurabelle.html 
DÍAZ VICTORIA, Juan. (2016). Estela de Finnegan: una lectura anotada del primer capítulo de Finnegans Wake de fames foyce. Arlequín.

ECO, Umberto. (1996). “Ostrigotta, ora capesco.” In Rosa Maria Bollettieri Bosinelli (Ed.), Fames foyce, Anna Livia Plurabelle (pp. V-XXIX). Einaudi.

ELLMAN, Richard. (1983). Fames foyce. Oxford University Press.

JOYCE, James. (1958). Finnegans Wake. Viking Press.

JOYGE, James. (2016). Finnegans Wake (M. Zabaloy, Trad.). Guenco de Plata. (Original work published in 1939).

LONG, Lynne. (2007). "History and Translation.” In Piotr Kuhiwczak and Karin Littau (Eds.), Companion to Translation Studies (pp. 63-76). Multilingual Matters Ltd.

MCGRATH, Andrew. (2014, April 22). "The Challenge of Translating Finnegans Wake." Melville House. Retrieved on o7 May 2021 from https://www.mhpbooks. com/the-challenge-of-translating-finnegans-wake/

MUNDAY, Jeremy. (2008). Introducing Translation Studies: Theories and Applications (2nd Edition). Routledge.

O’BRIEN, Edna. (2017, January 27). “Edna O’Brien: How James Joyce’s Anna Livia Plurabelle Shook the Literary World.” The Guardian. Retrieved on 15 February 2021 from https://www.theguardian.com/books/2017/jan/27/edna-obrienhow-james-joyces-anna-livia-plurabelle-shook-the-literary-world

O'NEILL, Patrick. (2005). Polyglot foyce: Fictions of Translation. Toronto University Press.

O’NEILL, Patrick. (2014). Impossible foyce: Finnegans Wakes. Toronto University Press.

SAVINO, Hugo. (2016, July 19). "Marcelo Zabaloy escribe una traducción” [Blog entry]. Entrelazos Blog. Retrieved on o7 May 2021 from https://entrelazosblog. wordpress.com/2016/07/19/marcelo-zabaloy-escribe-una-traduccion/

Symons, Arthur. (1899). The Symbolist Movement. E. P. Dutton \& Company. Tóibín, Colm. (2016, December 29). “Colm Tóibín: James Joyce’s Portrait of the Artist, 100 Years On.” The Guardian. Retrieved in 15 February 2021 from https:// 
www.theguardian.com/books/2016/dec/29/colm-toibin-james-joyce-a-portrait-of-the-artist-as-a-young-man

VÁZQUEZ, Cristian. (2017, July 16). "Finnegans wake, las traducciones del libro intraducible." Letras Libres (223). Retrieved on 15 February 2021 from https:// www.letraslibres.com/espana-mexico/revista/finnegans-wake-las-traducciones-del-libro-intraducible 